\title{
EFFECT OF MAGNETIZED WATER ON SOIL MOISTURE DISTRIBUTION AND DRIPPER DISCHARGE
}

\author{
ZABADY, F. I.
}

ABSTRACT

Recent researches indicate that if water is exposed to intense magnetic field, it is possible to obtain many positive effects on water properties that improve water use in irrigation applications. The magnetized water is obtained by passing water through permanent magnets installed on a feed pipe line. Therefore, this work was carried out to investigate of irrigation by magnetic water and its effects on soil moisture distribution under ultra-low drip irrigation and dripper discharge. Three treatments of magnetic (0.325, 0.495 and 0 Tesla) was carried out by using three nominal drippers discharge of 0.5, 1.2 and $2.0 \mathrm{l} / \mathrm{h}$ under effect of different pressures of 50,100, 150 and $200 \mathrm{kPa}$. The results indicated that the dripper discharge rate was increased by increasing the magnetic flux density at different dripper discharge rates and different operating pressures. Also, the moisture distribution pattern was increased horizontally more than vertically under dripper, by increasing the magnetic flux density at different operating pressures.

\section{INTRODUCTION}

$\mathrm{M}$ agnetized water is obtained by passing water through a permanent magnet installed in or on a feed pipeline. The mean soil moisture contents at depths of 0-20, 20-40, and 40-60 cm below the emitter for the magnetized irrigation water treatment were more than the non-magnetized irrigation water treatment (Behrouz et al., 2011). When water passes through the magnetized field, its structure and some physical characteristic such as density, salt solution capacity and deposition ratio of solid particles will be changed (Pang and Deng, 2008). Because of the limited water resources, better use of available water resources and use of recycled water with low and medium salinity for irrigation is important.

\footnotetext{
*Assoc. Prof., of Water \& Farm Irrigation Systems, Fac. of Ag. Eng., Al-Azhar Univ., Cairo.
} 
The use of poor-quality irrigation water with high salinity is one of the main problems in agriculture. To reclaim soil and water and to reduce soil moisture stress, magnetized water can be used (Kney and Parsons, 2006). The study revealed the performance of the sprinkler irrigation system was improved when that magnetized water was used compared with non-magnetized under the same operating and climatologically conditions, the degree of improvement depends on intensity of the magnetic field used under low and very low pressures, the most effective on uniformity was the intensity 0.1608 Tesla. The best performance of the system was achieved at 15 psi with direct magnetic flux density of 0.1608 Tesla. There variables have achieved the highest increase in irrigation uniformly compared with irrigation in normal water which was $24.2 \%$ (Al-Talib and Al-Sinjary, 2009).

The inverted magnets orientation (multi-pole and multi-reversing polarity magnetic field) yielded better results in effect on the molecules of dissolved solids and water molecules compared with non-inverted magnets orientation (Brower, 2005). The water like most molecules is diamagnetic; it is actually repelled by a magnet, although so weakly those sensitive instruments are needed to observe this effect. The structural group of water molecules, which consist of one oxygen molecule and two hydrogen molecules bonded as an isolated triangle with its upper angle of $105^{\circ}$ and water molecules under effect of magnetization. Generally, when water is subjected to a magnetic field, the water molecules will arrange in one direction. This mode of arrangement is caused by relaxation the bonds, and then the bond angle decreases to less than $105^{\circ}$, leading to a decrease in the consolidation degree between water molecules, and increase in size of molecules. For these reasons, the viscosity of magnetic water is less than viscosity of normal water. This change in water molecules composite causes a change in surface tension, $\mathrm{pH}$ and electrical conductivity (Ahmed, 2009). Magnetization increasing water $\mathrm{pH}$, total dissolved solids, boiling point and electrical conductivity and decreasing surface tension. Moreover, the magnetization effect on water properties was increased by increasing the magnetization time (El-Messery et al., 2015). 
The main objective of this study was to investigate soil moisture distribution and dripper discharge when using magnetic water. These studies were carried out on ultra-low drip irrigation at different operating pressures.

\section{MATERIALS AND METHODS}

The experiments were performed at the department of water and irrigation systems engineering, Faculty of Agricultural Engineering, Al-Azhar University, Nasr city, Cairo, Egypt. This study was made to measure dripper discharge rates at different magnetic flux intensity of 0.325 and 0.495 Tesla and measuring of water front advance horizontally and vertically for magnetized water.

\subsection{The experimental setup}

Fig. (1) shows the experimental setup which consists of water source and three lateral lines A, B, and C. Lateral A for treatment $0.325 \mathrm{~T}$, lateral B for treatment $0.495 \mathrm{~T}$ and lateral $\mathrm{C}$ for nonmagnetic water $(0 \mathrm{~T})$.

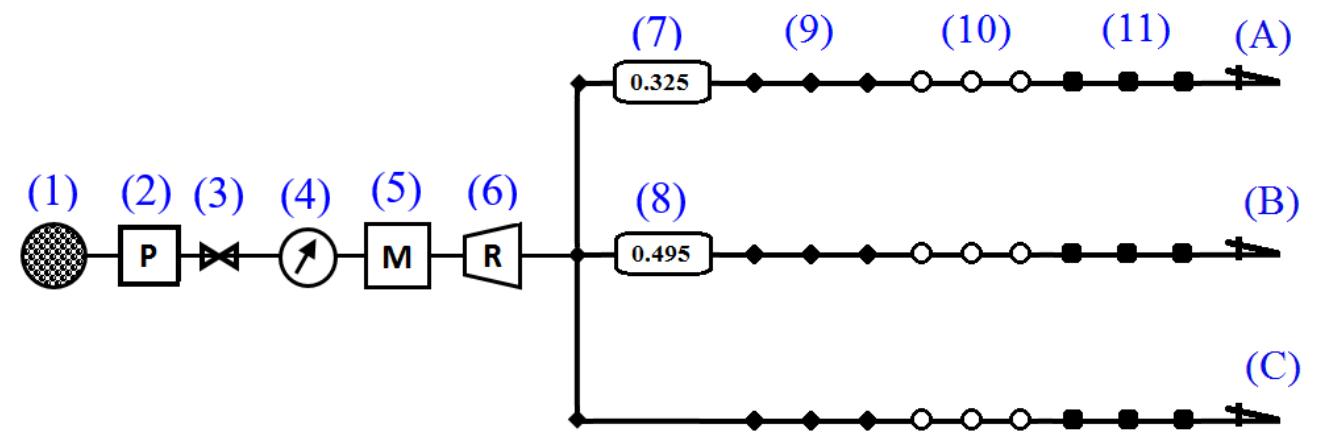

(1): Water source. $\quad$ (7): Inverted permanent Magnets 0.325 Tesla.

(2): Pump. $\quad$ (8): Inverted permanent Magnets 0.495 Tesla.

(3): Valve.

(9), (10), and (11): drippers 0.5, 1.2, and $2 \mathrm{~L} / \mathrm{h}$ respectively.

$\begin{array}{ll}\text { (4) Pressure gauge. } & \text { (A): } 0.325 \text { Tesla treatment. }\end{array}$

$\begin{array}{ll}\text { (5): Flow meter } & \text { (B): } 0.495 \text { Tesla treatment. }\end{array}$

(6): Pressure regulator. (C): Control Treatment. (0 Tesla)

Fig. (1): The experimental setup. 


\subsubsection{Soil Characteristics}

The soil characteristics were measured in the Laboratory of Soil and Water Department, Faculty of Agriculture, Al-Azhar University, Nasr City, Cairo, Egypt. The methodological procedures were done according to Klute (1986), Singh (1980) and Kohnke (1980) and the results are listed in Tables (1) and (2).

\subsubsection{Pump}

The water pump used in present study is Calpeda centrifugal pump. Its model name is NM 25/12A/A, made in Italy, $0.75 \mathrm{~kW}, 2900 \mathrm{rpm}$, single phase, inlet and outlet diameter are $25.4 \mathrm{~mm}\left(1^{\prime \prime}\right)$ and maximum discharge rate is $12 \mathrm{~m}^{3} / \mathrm{h}$.

Table (1): Physical characteristics of the soil under study.

\begin{tabular}{|c|c|c|c|c|c|c|c|c|}
\hline \multicolumn{4}{|c|}{ Particle size distribution (\%) } & \multirow{2}{*}{ 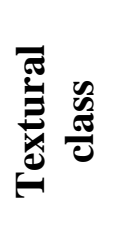 } & \multirow{2}{*}{ 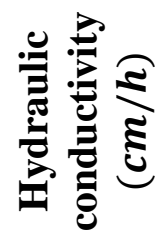 } & \multirow{2}{*}{$\bigodot_{0}^{\varrho}$} & \multirow{2}{*}{$\frac{a}{a} e^{e}$} & \multirow{2}{*}{ 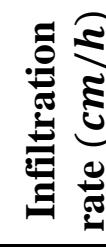 } \\
\hline $\begin{array}{c}\text { Coarse } \\
\text { sand }\end{array}$ & $\begin{array}{l}\text { Fine } \\
\text { sand }\end{array}$ & Silt & Clay & & & & & \\
\hline 48.3 & 28.8 & 18.7 & 4.2 & $\mathrm{~L} \mathrm{~S}^{(3)}$ & 9.68 & 12.6 & 4.13 & 2.032 \\
\hline
\end{tabular}

Table (2): Chemical characteristics of the soil under study.

Soluble ions in the saturated soil paste

\begin{tabular}{|c|c|c|c|c|c|c|c|c|}
\hline \multicolumn{4}{|c|}{ Cations $($ meq $/ L)$} & \multicolumn{3}{|c|}{ Anions $(\boldsymbol{m e q} / L)$} & \multirow[t]{2}{*}{$p H$} & \multirow{2}{*}{$\begin{array}{c}E c \\
d S / m\end{array}$} \\
\hline $\mathrm{Ca}^{++}$ & $\mathbf{M g}^{++}$ & $\mathrm{Na}^{+}$ & $\boldsymbol{K}^{+}$ & $\mathrm{Cl}^{-}$ & $\mathrm{HCO}_{3}^{-}$ & $\mathrm{SO}_{4}^{--}$ & & \\
\hline 9.45 & 6.69 & 2.43 & 0.54 & 5.10 & 4.91 & 9.10 & 7.80 & 1.91 \\
\hline
\end{tabular}

\subsubsection{Magnetization device (MD)}

The magnetization device consists of 5 pairs of permanent magnets arranged in an alternating configuration, these magnets were divided into two types, the first type dimensions was $(50 \times 25 \times 10 \mathrm{~mm})$ with magnetic flux density of $0.220 \mathrm{~T}$, while the second type dimensions was $(50 \times 25 \times 2 \mathrm{~mm})$ with magnetic flux density of $0.129 \mathrm{~T}$. 
The magnets were installed on two pieces of wood and can be controlled the distance between wood pieces through 4 bolts and nuts in the corners of wood pieces; the water pipe was made of stainless steel with external diameter of $17 \mathrm{~mm}$ and internal diameter of $14 \mathrm{~mm}$, as shown in Fig. (2).

\subsubsection{Emitters}

PCJ, on-line compact, pressure-compensated dripper, Netafim Ltd, the working pressure range are $20-400 \mathrm{kPa}$. The applications of these drippers are in greenhouses, nurseries, orchards, deciduous and trees irrigation. The emitters were installed on Poly Ethylene tube $16 \mathrm{~mm}$.

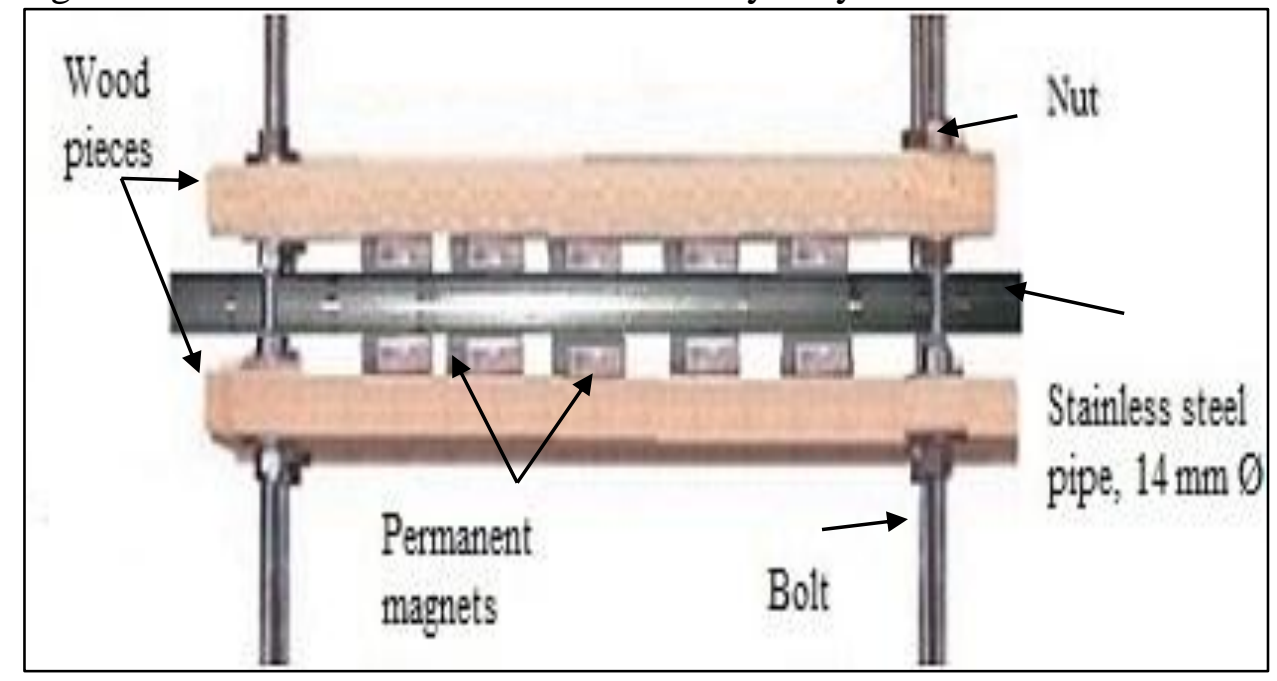

Fig. (2): Magnetization device, (El-Mesery et al., 2015).

\subsubsection{Plastic bags}

The soil samples were air dried, and put in transparent plastic bags which have cylindrical shape of $50 \mathrm{~cm}$ diameter and $60 \mathrm{~cm}$ depth. The samples were arranged under different discharge drippers of $0.5,1.2$, and $2 \mathrm{l} / \mathrm{h}$. Drippers were placed on the geometrical center at the top of soil samples. The application time was $42 \mathrm{~min}$. Two hour after application time, the wetted width (w) was measured. To determine the wetted depth (d), the bag sample was cut and the sample was split from the center accurately and slowly, then wetted depth (d) was measured.

\subsection{Measurements}

The experiment using magnets have magnetic flux densities of 0.325 and 0.495 Tesla, that were obtained by placing two or more magnets together and magnetic flux densities were measured in the center of water pipe by 
using Teslameter device (WUNTRONIC company in Germany, model: KOSHAVA-5) on the faculty of engineering, Tanta university. The type of magnets was inverted permanent magnets orientation, that means the adjacent and opposite magnets were different polarity, as shown in Fig. (2). Catch can be used to receive water from emitter to measure emitters flow rate. The scaled cylinder was used to measure it.

\section{RESULTS AND DISCUSSIONS}

\subsection{Water distribution}

Figures. (3) and (4) show the water distribution pattern at different magnetic flux density, different dripper discharge rate and different operating pressures. The results showed that the horizontal wetting front advance was increased and with high flux density for three types of dripper discharge rate and the vertical wetting front advance was decreased.

From Figures. (3) and (4) for dripper with nominal discharge rate of 0.5 $\mathrm{L} / \mathrm{h}$, the horizontal wetting front advance was $(8.8,11.3$, and $11.6 \mathrm{~cm})$, (10, 11.3, and 11.6), (9, 10.6 and 11) and (7.9, 8.2, and 9) at magnetic flux density of $0.0 .325,0.495$ Tesla respectively at operating pressures of $50,100,150$, and $200 \mathrm{kPa}$ respectively. The vertical wetting front advance was $(13,11$, and $10.4 \mathrm{~cm}),(12.5,11.5$, and 11.2), (14, 12 and 11.2) and (13.2, 11.7, and 10.8) at magnetic flux density of $0,0.325$, 0.495 Tesla respectively at operating pressures of 50,100, 150, and 200 $\mathrm{kPa}$ respectively.

For dripper with nominal discharge rate of $1.2 \mathrm{~L} / \mathrm{h}$, the horizontal wetting front advance was $(11.2,11.7$, and $11.9 \mathrm{~cm}),(11,11.9$, and 12.6), (10, 12.6 and 12.6) and $(9.7,10.6$, and 11.3) at magnetic flux density of 0. $0.325,0.495$ Tesla respectively at operating pressures of 50,100, 150, and $200 \mathrm{kPa}$ respectively. The vertical wetting front advance was (19, 18.6, and $17.5 \mathrm{~cm}),(19,17$, and 16.1), (19, 18 and 17.6) and (18, 17.3, and 17) at magnetic flux density of $0,0.325,0.495$ Tesla respectively at operating pressures of $50,100,150$, and $200 \mathrm{kPa}$ respectively for dripper with nominal discharge rate of $0.5 \mathrm{~L} / \mathrm{h}$. 

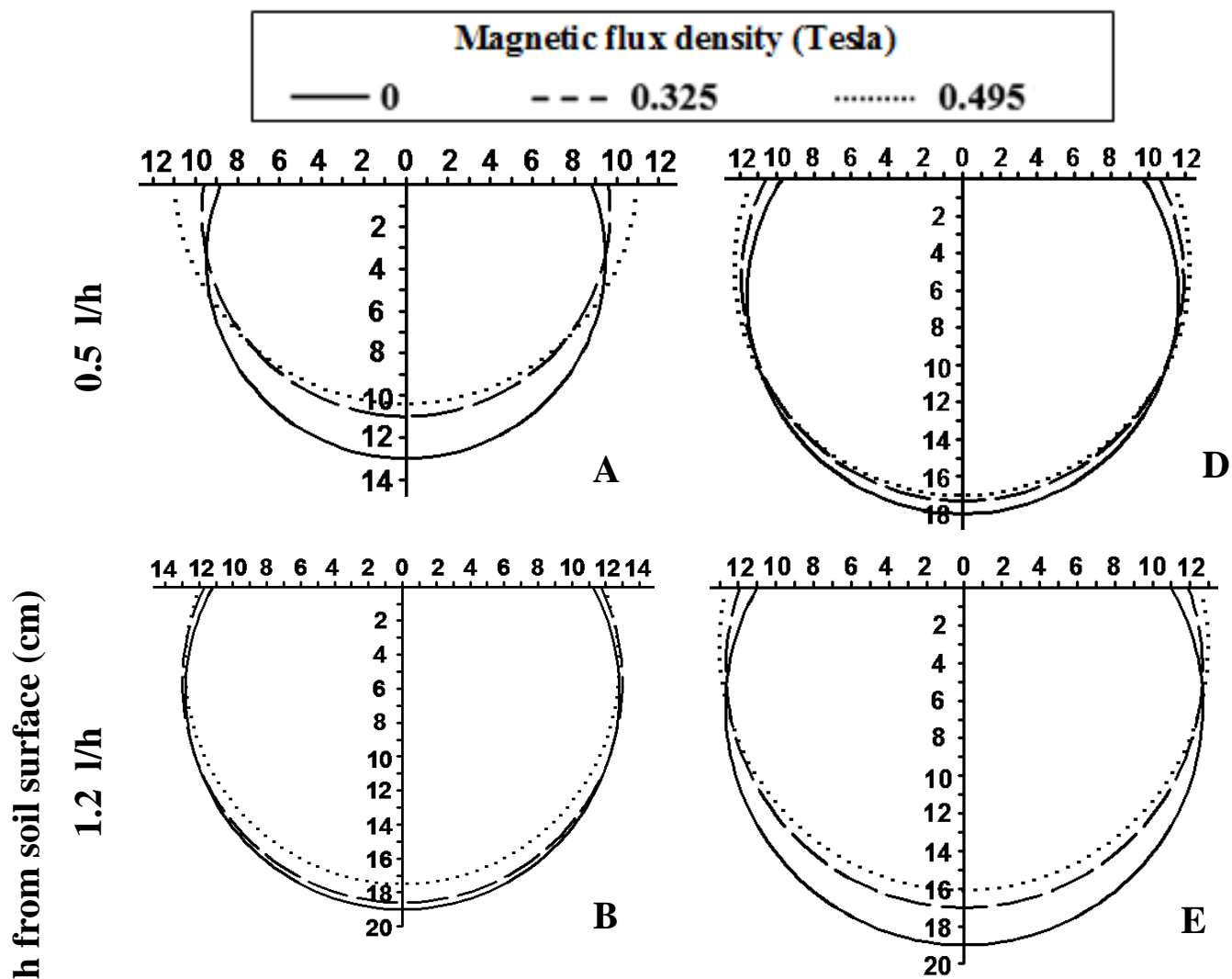

高

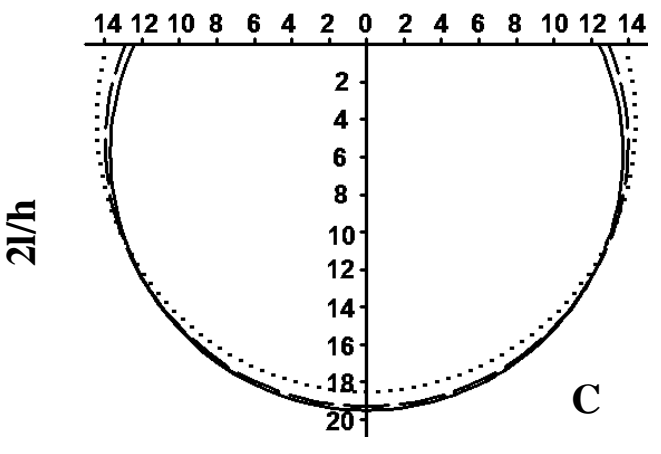

$150 \mathrm{kPa}$

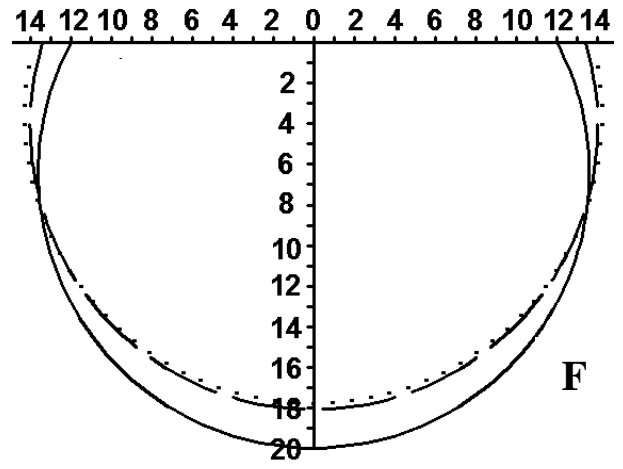

Horizontal distance from dripper $(\mathrm{cm})$

Fig. (3):Water distribution pattern at different magnetic flux density, different dripper discharge rates and operating pressures (150 and 200 bar). 

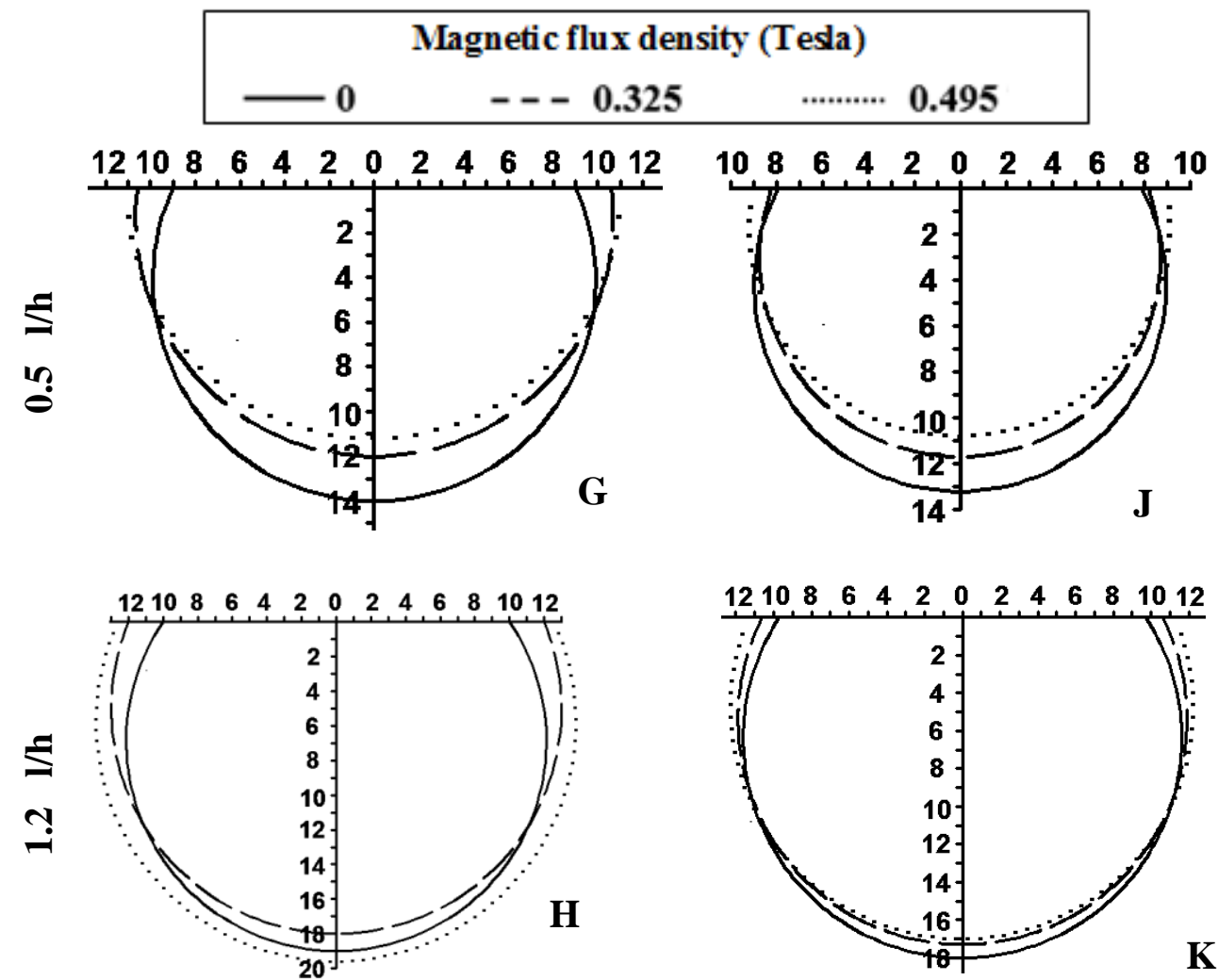

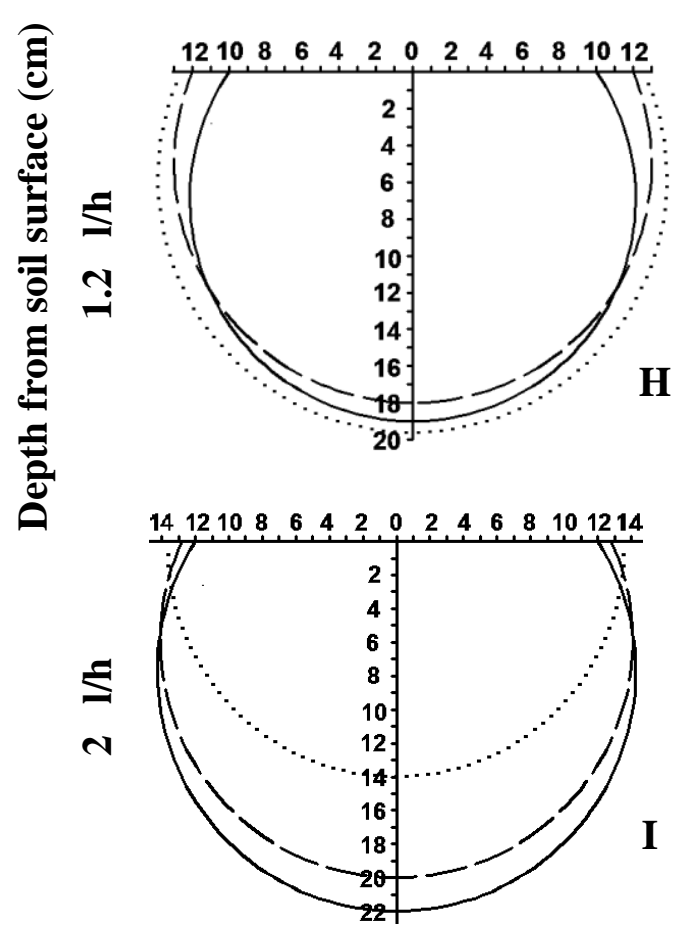

$100 \mathrm{kPa}$

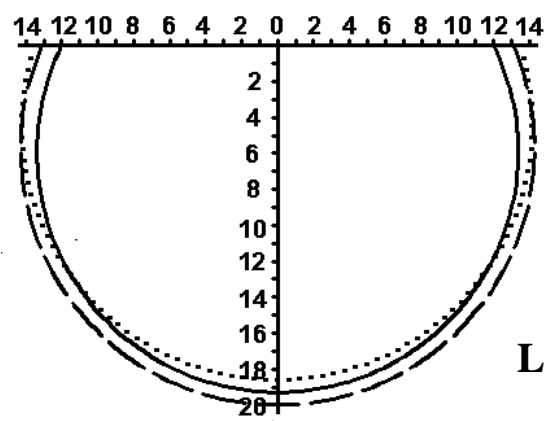

$50 \mathrm{kPa}$

Horizontal distance from dripper $(\mathrm{cm})$

Fig. (4):Water distribution pattern at different magnetic flux density, different dripper discharge rates and operating pressures (50 and 100 bar). 
For dripper with nominal discharge rate of $2 \mathrm{~L} / \mathrm{h}$, the horizontal wetting front advance was $(12.4,12.9$, and $13.8 \mathrm{~cm}),(12,13.4$, and 13.8), (12, 12.8 and 13.6) and $(12,13.1$, and 13.5) at magnetic flux density of 0 , $0.325,0.495$ Tesla respectively at operating pressures of 50,100,150, and $200 \mathrm{kPa}$ respectively. The vertical wetting front advance was (19.5, 19.3, and $18.5 \mathrm{~cm}),(20,18.1$, and 17.8), (22, 120 and 14) and (19.3, 19, and 18.6) at magnetic flux density of $0,0.325,0.495$ Tesla respectively at operating pressures of $50,100,150$, and $200 \mathrm{kPa}$ respectively for dripper with nominal discharge rate of $0.5 \mathrm{l} / \mathrm{h}$.

These results may be due to the rotational motions got slow after magnetic treatments. The results suggested that the average size of water clusters became larger by magnetic treatments, this result agreement with Al-Talib and Al-Sinjary, (2009).

\subsection{Dripper discharge rate}

The relation between dripper discharge rate and operating pressures of 50, 100,150 , and $200 \mathrm{kPa}$ at different magnetic water flux density $0,0.325$, and 0.495 Tesla.

From Fig. (5) The dripper discharge rate was increased at high magnetic flux density. For dripper with nominal discharge rate of $0.5 \mathrm{~L} / \mathrm{h}$, the dripper discharge rate increased from $(0.48,0.50$, and $0.52 \mathrm{~L} / \mathrm{h}),(0.49$, 0.50 , and 0.52), (0.50, 0.52, and 0.52) and (0.50, 0.54, and 0.55) respectively at operating pressures of $50,100,150$, and $200 \mathrm{kPa}$.

For dripper with nominal discharge rate of $1.2 \mathrm{~L} / \mathrm{h}$, the dripper discharge rate increased from $(1.14,1.16$, and $1.18 \mathrm{l} / \mathrm{h}),(1.15,1.17$, and 1.19), $(1.18,1.25$, and 1.27$)$ and $(1.20,1.31$, and 1.32$)$ respectively at operating pressures of 50, 100, 150, and $200 \mathrm{kPa}$.

For dripper with nominal discharge rate of $21 / \mathrm{h}$, the dripper discharge rate increased from $(1.92,1.95$, and $1.95 \mathrm{l} / \mathrm{h}),(2.04,2.13$, and 2.16), (2.10, 2.20 , and 2.24$)$ and $(2.15,2.19$, and 2.22$)$ respectively at operating pressures of 50, 100, 150, and $200 \mathrm{kPa}$. 

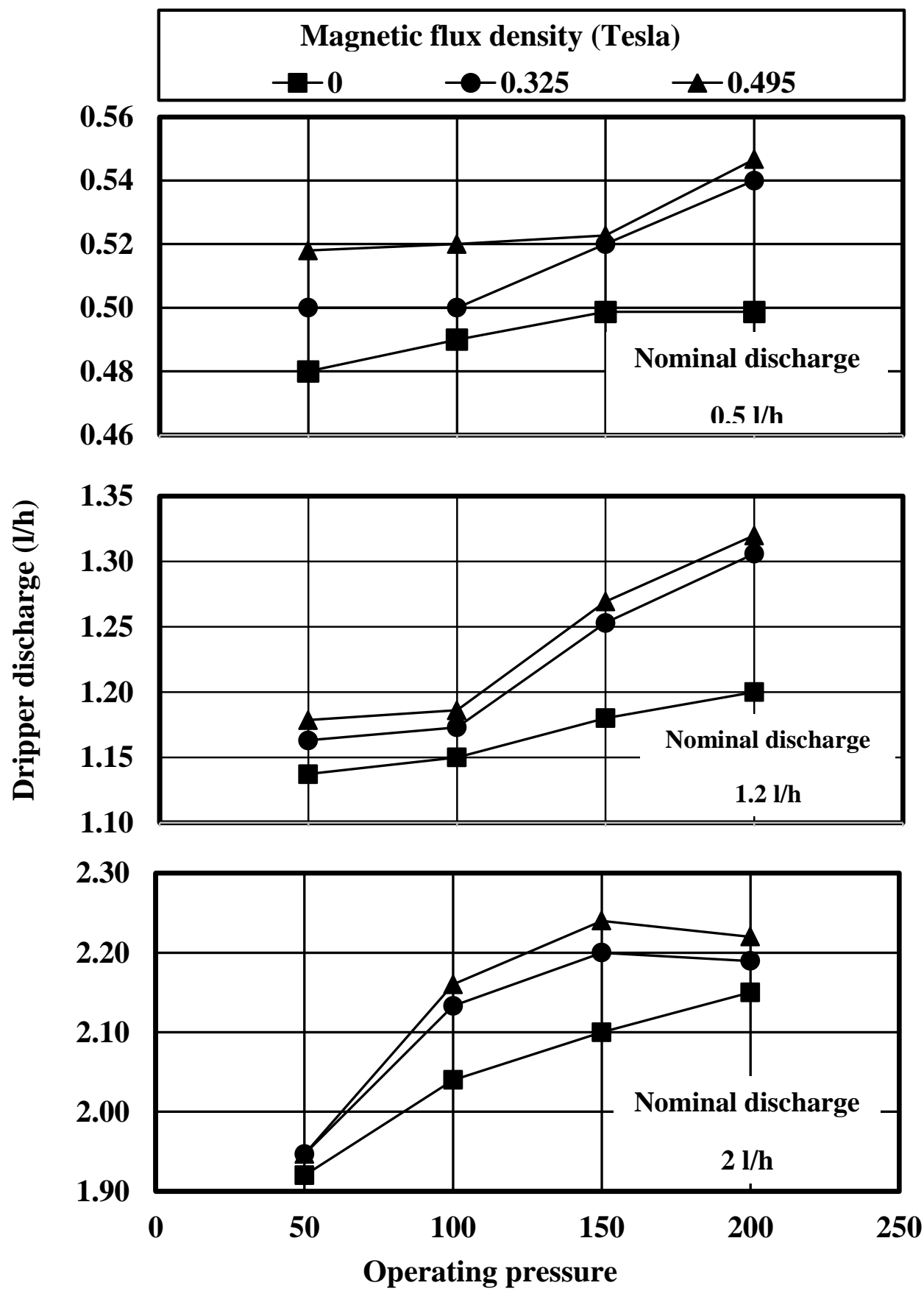

Fig (5): Relation between dripper discharge rate (1/h) and operating pressure (bar), at different magnetic flux density (Tesla) with different nominal dripper discharge $(\mathrm{L} / \mathrm{h})$. 
These results may be due to a decrease in the consolidation degree between water molecules. For these reason, the viscosity of magnetic water is less than viscosity of non-magnetic water. This result agreement with AbdelTawab et al., (2011).

\section{CONCLUSION}

The study has revealed that the performance of the ultra-low drip irrigation system improved by using the magnetized water, compared to non-magnetized under the same operating and climatology conditions. The degree of improvement depends on the magnetic flux densities used.

The use of magnetized water for irrigation is recommended to:

- Maximize soil moisture holding capacity and minimize soil moisture deep percolation.

- Prevent water table contamination with ammonia especially in sandy soil.

- The rotational motions got slow down after magnetic treatments, agreement with the results obtained by (Al-Talib and Al-Sinjary, 2009).

\section{REFERENCES}

AbdelTawab, R. S., M. A. Younes, A. M., Ibrahim and M. M., AbdelAziz, (2011). Testing commercial water magnetizers: A study of TDS and $p H$. Fifteenth International Water Technology Conference, IWTC - 15 2011, Alexandria, Egypt.

Ahmed, S. M. (2009). Effect of Magnetic Water on Engineering Properties of Concrete, Al-Rafidain Eng. J., 17 (1): 71 - 82. $\leq$ http://www.uom-arej.org/OldSite/files/no1/E/F-1-6-2009.pdf $>$ 
Al-Talib, A. A. and Z. A. Al-Sinjary, (2009). Effect of magnetizing water on uniformity of sprinkle irrigation. Al-Rafidain Eng. J. 17 (1): $68-79$.

Behrouz, M. F.; M. Khoshravesh; S. F. Mousavi and A. R. Kiani (2011). Effects of Magnetized Water and Irrigation Water Salinity on Soil Moisture Distribution in Trickle Irrigation, J. Irrig. Drain. Eng., 137:398-402.

$<$ https://www.researchgate.net/publication/274428769_Effects_of_Magne tized_Water_and_Irrigation_Water_Salinity_on_Soil_Moisture_Dis tribution_in_Trickle_Irrigation>

Brower, J. (2005).Magnetic Water Treatment, Pollution Engineering:2628. $\leq$ https://www.highbeam.com/doc/1G1-128869227.html>

El-Mesery A. A.; F. I. Zabady; A. E. Abd El-Hameed and T. M. ElZanaty (2015). Study of some engineering factors affecting magnetization of irrigation water, Year book of Misr soc. of Ag. Eng., the $20^{\text {th }}$ Annual Conference of Misr J. of Ag. Eng., :413 426.

Klute, A., (1986). Water retention: Laboratory methods. Chapter 26. Hand book of Methods of soil Analysis. Part 1. $2^{\text {nd }}$ Ed Am. Soc. Argon. Soil Sci. Am., Madison, WI. USA. pp 277-294.

Kney, A. D. and S. A. Parsons (2006). A spectrophotometer-based study of magnetic water treatment: Assessment of ionic vs. surface mechanisms, Water Res., 40(3): 517-524.

<http://www.sciencedirect.com/science/article/pii/S004313540500669X> 


\section{$\leq$ http://www.sciencedirect.com/science/S185811050417>}

Kohnke, H., (1980). Soil Physics. Soil Scientist. Purdue Univ., TATA, Mc Grew Hill. Publishing Company Ltd., New Delhi, India, :28-34.

Pang, X. F. and B. Deng (2008). Investigation of Changes in Properties of Water Under the Action of a Magnetic Field, Sci. China Ser. GPhys. Mech. Astron, 51 (11): 1621-1632.

Singh, R. A., (1980). Soil physical analysis. MRS., U.R.K., New Delhi, India: 75-94.

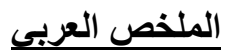

\section{تأثير الماء الممغنط على انتثار الرطوبة فى التربة وتصرف النقاط}

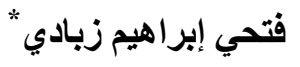

تشير الدراسات الحديثة إلى أنه من الممكن الحصول على العديد من التأثيرات الإيجابية في مجال الري عند تعرض المياه لمجال مغناطيسي بكثافة فيض معينة تؤثر على فى خواص الماء.

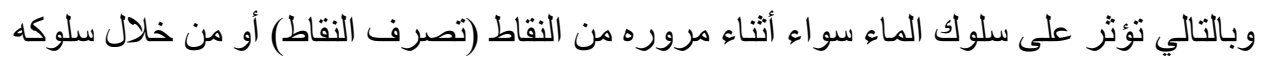

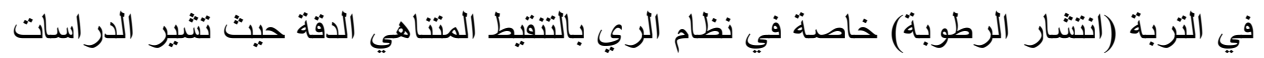

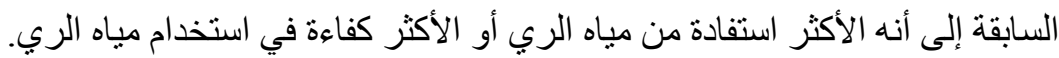

وفى الدر اسة الحالية تمت مغنطة مياه الري بتسليط مجال مغناطيسي مستمر على أنبوب المصدر المائي المغذى لثبكة الري بالتتقيط.

يتضمن هذا البحث إجر اء مجموعتين من التجارب، المجموعة الأولى: خاصة بقياس التصرف

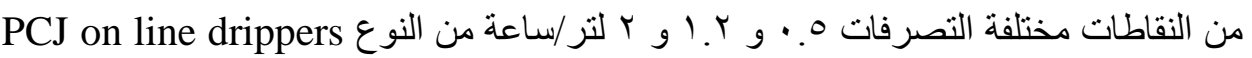

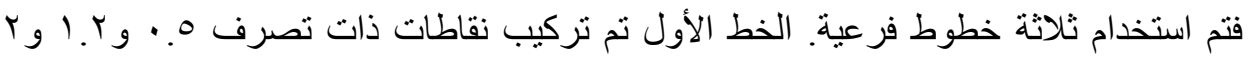

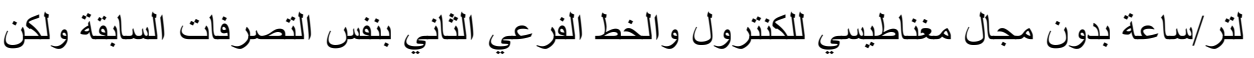
بشدة مجال مغناطيسي هبr. • تسلا والخط الثالث أيضاً بنفس التصرفات ولكن بشدة مجال مغناطيسي 90 ؛. • تسلا. وتم استخدام أو عية لتجميع المياه.

*أستاذ هندسة نظم المياه والرى المساعد _ كلية الهندسة الزراعية بالقاهرة - جامعة الأزهر. 
والمجموعة الثانية من التجارب تم وضع التربة المجفقة هو ائياً في أكياس ذات قطر ـ سم

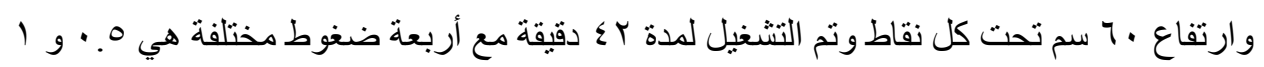
و ه. 1 و r بار وتم قياس انتشار الرطوبة تحت كل معاملة في الاتجاه الأفقي و الر أسي و القطري. أظهرت النتائج أنه بزيادة كثافة الفيض المغناطيسى يزداد تقدم جبهة البلل فى الإتجاه الأفقى عنه

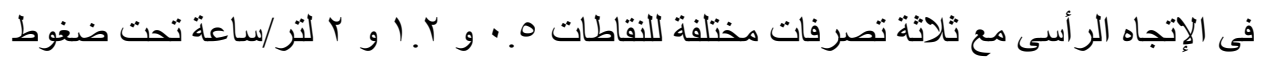

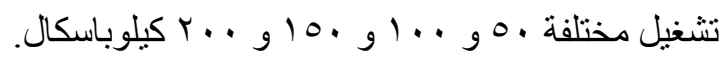

كما أظهرت النتائج أنه بزيادة كثافة الفيض المغناطيسى يزداد تصرف النقاط تحت ضغوط التشغيل المختلفة. 